\title{
学生相談機関のイメージ及び周知度と来談意思の関係
}

\author{
伊藤直樹 明治大学
}

\section{The image and familiarity of student counseling service and willingness to use the service}

\author{
Naoki Ito (Meiji University)
}

\begin{abstract}
The purpose of this study was to investigate the relationship between image and familiarity that college students had about student counseling service and their willingness to make use of the service. A questionnaire was administered to 421 college students. Factor analysis of the image found two positive sides: helpfulness and support in crisis, and two negative ones: disadvantage and uneasiness. Men had an image that was higher on support in crisis and disadvantage than women. Women were more familiar with the service, but no sex difference was found in the willingness to visit it. First-year students were lower in terms of their familiarity, but no image differences were found among students of different years. Regression analysis of the willingness indicated that different predictors became significant, depending on the sex and year of the respondents. It was suggested that different information about counseling service should be disseminated, so as to maximize the willingness, depending on the sex and year of the students.
\end{abstract}

Key words: college students, student counseling service, image, familiarity, willingness.

The Japanese Journal of Psychology

2006, Vol. 76, No. 6, pp. 540-546

最近, 大学生の不適応が急増し，それと並行するよ うに, 大学内の学生相談機関の利用者も増加傾向にあ ると言われる（文部省高等教育局・大学における学生 生活の充実に関する調査研究会，2000）。アメリカの 学生相談機関への学生の来談率については, 10-30\% と報告したものが多い (Clary \& Fristad, 1987; 森, 1990)。一方, 日本学生相談学会特別委員会（2001） の 2000 年度の調查によれば, 日本では大学で来談率 が $2.8 \%$, 短期大学で $5.5 \%$ であり, 最近の利用者の増 加傾向にもかかわらず，全体としては依然として来談 率が低い状況であると言えよう。学生の来談率が高ま れば, 不適応状態に陥った学生に適切な援助が行われ る可能性も高まると考えられる。

学生の来談行動について, 高野・宇留田 (2002) は, 学生の “援助要請行動”としてモデル化し, 学生 が援助要請行動を取る際の負担として, 設備面でのア クセスのしやすさなどの “経済的・物質的コスト” と, 援助を要請すること自体に付随する心理面での負 担 (“心理的コスト”) を挙げている。そして, 学生の 来談には“心理的コストを下げるために，相談機関に

Correspondence concerning this article should be sent to: Naoki Ito, School of Arts and Letters, Meiji University, KandaSurugadai, Chiyoda-ku, Tokyo 101-8301,Japan(e-mail: iton@ kisc.meiji.ac.jp)
対するイメージを改善すること”が重要であることを 指摘している。

アメリカでは，この領域に関しては，相談すること に対する “認知” (perception), “期待” (expectation), “態度” (attitude) などの視点から研究が行わ れている。

“認知”という視点からは, “学生相談機関で相談す るのに適切な問題” に対する認知についての研究があ り, 教職員, 一般学生, 来談学生における相談への適 切性の認知の差異が有効な利用を妨げていることが指 摘されている (Sanders \& Sanders, 1985)。また, 個人 や小集団を志向したオリエンテーションが適応問題を 相談することへの適切性の認知を高め, 利用可能性を 高めるという指摘もある（Miles \& McDavis, 1982）。

“期待”という視点からは, カウンセリング期待尺 度 (The Expectation About Counseling Scale: 以下 EAC とする; Tinsley, Workman, \& Kass, 1980）を用 いた研究が挙げられる。EACを用いた研究には, 性 別, 学生が抱えている問題の有無, 人種の差異による カウンセリングへの期待の差異について明らかにしょ うとしたものが多く, Kemp（1994）は, マイノリテ イの学生の来談の促進のためには彼らを取り巻く大学 内の諸環境を改善することが重要であることを指摘し ている。 
“態度”という視点からは, Fischer \& Turner （1970）の作成した “専門的心理的援助への態度尺度” (The Attitudes Toward Seeking Professional Psychological Help Scale：以下ATSPPH とする）を用いた 援助要請行動に関する一連の研究があり, 日本でも水 野・石隈（1999）によって紹介されている。Komiya, Good, \& Sherrod (2000) はATSPPHを用いた研究 により，自己開示性を高めることが心理的援助を受け ることへの偏見を低減し，来談を促進すると指摘して いる。

一方，日本ではこの点に関して，SD 法や自由記述 式の質問紙を用いて学生相談機関のイメージという視 点から行われる研究が多い（荻原・吉川・山田, 1995; 真覚・中村, 1993; 櫻井・有田, 1994)。しか し, これらの研究はイメージの分類の妥当性について 問題が残り, また, 学生相談機関のイメージと来談と の関係について直接的な示唆を与えるものではない。

これに対し，森田（1997）は学生相談室に来談した 学生を対象にした研究から, 学生の持つイメージによ り来談, 相談の継続性, 相談内容などに違いが見られ たと報告しているが，実験参加者が少ないこと，来談 しない学生も含めた検討が必要であることなどの課題 が残されている。来談しない学生も含めた研究として は, 西河・鈴木（1994）が学生相談室の利用希望あり の学生のイメージは全般的によく, それが 1 年後も継 続していたと報告している。

これらの研究からも学生相談機関のイメージが学生 の来談行動に影響を与えることが推測されるが, 両者 の関係について，より具体的に分析した研究は見られ ない。

ところで, 学生の来談を考える際には, 学生相談機 関についての情報をどの程度得ているか，すなわち， 周知度も重要な要因の一つであると言えよう。周知度 に関しては，アメリカではJohnson, Nelson, \& Wooden（1985）などの研究があるが, 来談との関連 を探ったものは見られない。これに対し，伊藤 (2002) は学生の周知度と実際の来談者数に関連があ ることを指摘している。学生相談機関の周知度が高ま ることは, 学生が問題を抱えた際に, 学生相談機関を 訪れるまでに必要となる負担を減少させ, 結果とし て，来談の促進につながることが予想される。

以上, 先行研究を概観すると, アメリカの研究で は，学生相談機関自体に対するイメージを扱っていな いこと, 日本の研究では，イメージの分類を実証的に 確認したものや周知度を扱ったものが少なく，また， 来談意思との関連を扱ったものが少ないという問題点 が挙げられる。

そこで, 本研究では, 上述のような先行研究の知見 や問題点を踏まえ, まず, 学生が学生相談機関に対し て実際に持っているイメージを測定する質問紙を作成
し，それを用いた調査から学生相談機関イメージの分 類を行う。さらに, 学生相談機関のイメージ及び周知 度と来談意思の関係について示唆を得ることを目的と する。

\section{方法}

予備調査 2001 年 11 月に大学 $1-3$ 年生 46 人（男 子 33 人，女子 13 人）を対象にして学生相談機関に対 するイメージをたずねる自由記述式の質問紙を実施 し, 学生の学生相談機関へのイメージに関する表現を 収集した。

質問紙の作成 櫻井・有田 (1994), 西河・鈴木 (1994), 荻原他（1995）, 森田（1997）及び予備調査 の回答の中から，学生相談機関のイメージについての 記述 235 個を抽出した。次に，KJ 法を用いて項目の 整理を行い, 学生相談機関イメージ項目（55 項目） を選定した。

周知度については, Kahn, Wood, \& Wiesen (1999) を参考にして，学生相談機関の“存在”, “場所”, “開 室日時”についてたずねる項目（3項目）を作成し た。

来談意思については，下山・峰松・保坂・松原・ 林・齋藤（1991）における分類を参考に, 現在及び将 来に悩みや不安を抱えた時，学生相談機関を利用した い程度をたずねる項目（2項目）と，“学業”，“進 路”, “就職”, “性格”, “対人関係”, “家庭”, “経済”, “精神衛生”に関する不安や悩みの種類別に利用した い程度をたずねる項目（8 項目）の合計 10 項目を作 成した。なお，ここでいう来談意思とは，自分が悩み や不安を抱えた場合に学生相談室を利用するか否かに ついての予測であり，実際の来談行動を推測するため の指標である（Blier, Atkinson, \& Geer, 1987）。

これらを合わせた 68 項目からなる質問紙を本調査 に用いた。なお，学生相談機関イメージと不安や悩み 別の来談意思は 5 件法により, 現在及び将来の来談意 思と周知度は 4 件法により回答を求めた。

本調査 本調查は 2001 年 12 月 -2002 年 1 月に 3 大学の 1-4 年生 349 人を対象に, 授業時に一斉に実 施するか手渡し式で実施した。3，4年生の実験参加 者が少なかったため, 2004 年 7 月にさらに1大学の 3,4 年生 146 人を対象に調査を実施した。すべての 項目に回答した 421 人 (1 年生 221 人, 2 年生 42 人, 3 年生 77 人, 4 年生 81 人, 男子 202 人, 女子 219 人) を分析の対象とした。

\section{結 果}

学生相談機関イメージの構造の分析 学生相談機関 イメージ項目 55 項目のうち, 項目間の相関が $r>.7$ 以上のペアの片方及び分布に偏りが見られた 2 項目を 除外した。残りの53 項目について固有值 1 を基準に 
Table 1

学生相談機関イメージ項目の因子分析結果（バリマックス回転後）

\begin{tabular}{|c|c|c|c|c|}
\hline 項 目 & $\mathrm{F} 1$ & $\mathrm{~F} 2$ & F3 & $\mathrm{F} 4$ \\
\hline 21. 学生にとってありがたいところ & .770 & -.057 & -.018 & -.070 \\
\hline 28. 役に立つところ & .747 & -.099 & -.117 & -.099 \\
\hline 9. 学生にとって心強いところ & .732 & -.080 & -.055 & -.138 \\
\hline 2. 頼りになるところ & .702 & -.018 & -.166 & -.171 \\
\hline 22. 信頼できるところ & .675 & .022 & -.286 & -.132 \\
\hline 36. 便利なところ & .636 & -.087 & .158 & -.164 \\
\hline 46. 適切なアドバイスを与えてくれるところ & .610 & .055 & -.230 & -.038 \\
\hline 5. 学生のために良いことをしているところ & .608 & -.009 & -.090 & -.024 \\
\hline 43. 学生のためにがんばっているところ & .596 & .103 & -.160 & -.087 \\
\hline 3. 学生のことを真剣に考えてくれるところ & .589 & .055 & -.281 & -.077 \\
\hline 14. 学生生活に必要なところ & .565 & -.083 & .044 & -.114 \\
\hline 41. 悩みを解決してくれるところ & .560 & .132 & -.148 & -.021 \\
\hline 32. やさしい先生がいるところ & .501 & .229 & -.124 & -.244 \\
\hline 1. 専門家として相談にのってくれるところ & .456 & .072 & -.268 & -.062 \\
\hline 52. 追いつめられている人が行くところ & -.026 & .739 & .018 & .166 \\
\hline 12. 自分で悩みを解決できない人が行くところ & .001 & .680 & .123 & -.104 \\
\hline 27. 絶望した人が行くところ & .019 & .674 & .114 & .106 \\
\hline 7. ひどく悩んでいる人が行くところ & .017 & 636 & -.151 & .099 \\
\hline 40. 精神的に弱い人が行くところ & -.117 & 634 & .268 & .052 \\
\hline 35. いじめにあっている人が行くところ & .048 & .618 & .233 & .082 \\
\hline 25. どうしようもなくなったら行くところ & .026 & .587 & -.083 & .278 \\
\hline 17. 人に言えない悩みがある人が行くところ & .196 & .584 & -.238 & .135 \\
\hline 6. 相談相手がいない人が行くところ & -.161 & .574 & .234 & -.009 \\
\hline 51. 自分のことを決められない人が行くところ & -.189 & .534 & .282 & -.054 \\
\hline 29. 神経質な人が行くところ & -.083 & .512 & .326 & .024 \\
\hline 13. 不安なことがある人が行くところ & .274 & .483 & -.091 & .090 \\
\hline 10. 何かトラブルがあった人が行くところ & .185 & .428 & .068 & .155 \\
\hline 48. お説教されるところ & -.161 & .049 & .636 & .167 \\
\hline 37. 相談すると不利益がありそうなところ & -.173 & .117 & .601 & .139 \\
\hline 19. 甘えている人が行くところ & -.149 & .249 & .530 & -.011 \\
\hline 15. 相談したことが外部にもれそうなところ & -.071 & .087 & .433 & .039 \\
\hline 31. 事務的・機械的な対応をするところ & -.190 & .047 & .416 & .250 \\
\hline 18. 近寄りがたいところ & -.214 & .154 & .127 & 636 \\
\hline 54. 相談に行きにくいところ & -.267 & .285 & .151 & .582 \\
\hline 33. できれば行きたくないところ & -.236 & .306 & .163 & .505 \\
\hline 34. 何をしているかよくわからないところ & -.287 & .092 & .158 & .471 \\
\hline 各因子によって説明される分散 & 6.184 & 5.050 & 2.421 & 1.730 \\
\hline
\end{tabular}

因子分析（主因子解, バリマックス回転）を行い, 比 較的解釈がしやすい 4 因子を得た（Table 1)。因子負 荷の高い項目から第 1 因子を“有益イメージ” 因子, 第 2 因子を “危機支援イメージ” 因子, 第 3 因子を “不利益イメージ”因子, 第 4 因子を“不気味イメー ジ”因子と解釈した。

学生相談機関イメージ尺度の作成 各因子への因子 負荷が .40 以上の項目により尺度構成を行い, 実験参
加者ごとに各項目の粗点の和を項目数で除した得点に より学生相談機関イメージ得点を算出した。これら 4 尺度について Cronbach の $\alpha$ 係数及び尺度間相関を求 めたところ “不利益イメージ”で若干值が低かった が，お打むね内的一貫性には問題がないと思われた (Table 2)。

周知度得点及び来談意思得点の算出 周知度につい ては 3 項目の粗点の和を周知度得点とした。また, 来 
Table 2

学生相談機関イメージ・周知度・来談意思尺度間の相関

\begin{tabular}{|c|c|c|c|c|c|c|c|c|}
\hline & 平均 & $S D$ & $\alpha$ 係数 & 有益 & 危機支援 & 不利益 & 不気味 & 周知度 \\
\hline 有 益 & 3.314 & .639 & .907 & - & - & - & - & - \\
\hline 危機支援 & 3.012 & .699 & .879 & -.005 & - & - & - & - \\
\hline 不利益 & 2.230 & .645 & .696 & $-.364^{* *}$ & $.266^{* *}$ & - & - & - \\
\hline 不気味 & 3.365 & .830 & .766 & $-.436^{* *}$ & $.355^{* *}$ & $.373^{* *}$ & - & - \\
\hline 周知度 & 6.202 & 2.560 & .840 & $.111^{*}$ & -.035 & $-.120^{* *}$ & $-.170^{* *}$ & - \\
\hline 来談意思 & 27.786 & 7.204 & .833 & $.471^{* *}$ & .068 & $-.167^{* *}$ & $-.302^{* *}$ & $.164^{* *}$ \\
\hline
\end{tabular}

Table 3

学生相談機関イメージ・周知度・来談意思の性差・学年差

\begin{tabular}{|c|c|c|c|c|}
\hline & \multicolumn{2}{|c|}{ 性 別 } & \multicolumn{2}{|c|}{ 学 年 } \\
\hline & 男子 & 女子 & 1 年生 & 2-4 年生 \\
\hline 有＼cjkstart益 & $3.278 \quad(.687)$ & $3.348 \quad(.591)$ & $3.278 \quad(.636)$ & $3.355(.641)$ \\
\hline 危機支援 & $3.086(.764)$ & $2.943(.628)$ & $3.017(.670)$ & $3.005(.732)$ \\
\hline 不利益 & $2.351 \quad(.711)$ & $2.118(.557)$ & $2.278 \quad(.699)$ & $2.176(.576)$ \\
\hline 不気味 & $3.365(.856)$ & $3.364(.807)$ & $3.372(.837)$ & $3.356(.824)$ \\
\hline 周知度 & $5.792(2.629)$ & $6.580(2.440)$ & $5.891 \quad(2.542)$ & $6.545(2.542)$ \\
\hline 来談意思 & $27.594(7.758)$ & $27.964(6.666)$ & $28.019(6.592)$ & $27.529(7.834)$ \\
\hline
\end{tabular}

Table 4

来談意思を目的変数とした回帰分析

\begin{tabular}{|c|c|c|c|}
\hline & 予測変数（ $\beta$ 值） & $R^{2}$ & $F$ 値 \\
\hline 全 体 & 有益 $(\beta=.390)$, 危機支援 $(\beta=.131)$, 周知度 $(\beta=.098)$, 不気味 $(\beta=-.162)$ & .257 & $36.041^{* *}$ \\
\hline 1 年男子 & 有益 $(\beta=.513)$ & .263 & $37.417^{* *}$ \\
\hline 1 年女子 & 有益 $(\beta=.317)$, 周知度 $(\beta=.207)$ & .170 & $11.648^{* *}$ \\
\hline 2-4 年男子 & 有益 $(\beta=.509)$, 周知度 $(\beta=.203)$ & .304 & $20.766^{* *}$ \\
\hline $2-4$ 年女子 & 不気味 $(\beta=-.540)$, 危機支援 $(\beta=.305)$, 不利益 $(\beta=-.198)$ & .362 & $18.519 * *$ \\
\hline
\end{tabular}

談意思に関しては，4件法で回答させた項目の粗点を $5 / 4$ 倍し， 5 件法の得点のレンジと合わせた得点と, 内容別の来談意思の粗点を加えた得点を来談意思得点 とした。両尺度の $\alpha$ 係数は Table 2 に示す通りであ り，いずれも内的一貫性には問題がないと思われた。

学生相談機関イメージ及び周知度と来談意思の関係 学生相談機関イメージと来談意思の相関を求めたとこ ろ, Table 2 下段のようになった。“有益イメージ” は来談意思 $(r=.471, p<.01)$ との間に有意な正の相 関が見られた。これに対し“不利益イメージ”及び “不気味イメージ”は来談意思との間にそれぞれ $r=-.167(p<.01), r=-.302(p<.01)$ の有意な負の 相関が見られた。周知度と来談意思の相関を見たとこ ろ, $r=.164(p<.01)$ の有意な正の相関が見られた。

性差・学年差の分析 学生相談機関イメージ, 周知
度及び来談意思の性差・学年差を検討するために性 別×学年の 2 要因の分散分析を行った。学年差につい ては学年間の人数差を考慮し, 1 年生と 2-4 年生の 2 群に分け分析した。その結果, “危機支援” $(F(1$, $417)=4.411, p<.05)$, “不利益” $(F(1,417)=13.784$, $p<.01)$ で男子が女子より有意に得点が高く, 周知度 は女子が男子より有意に得点が高かった（ $F(1$, $417)=11.034, p<.01)$ 。また, 学年差については周知 度のみ $2-4$ 年生が 1 年生より有意に得点が高かった $(F(1,417)=7.189, p<.01)$ 。なお, いずれも交互作 用は見られなかった (Table 3$)$ 。

来談意思の予測 来談意思に影響を及ぼす要因をさ らに探るために，学生相談室イメージ及び周知度を予 測変数, 来談意思を目的変数としてステップワイズ方 式の回帰分析を行った。学生相談機関イメージ及び周 
知度にいくつかの性差，学年差が見られたことから， 全体の分析に加え， 1 年生男子， 1 年生女子， $2-4$ 年 生男子， 2-4 年生女子の 4 群に分けて分析を行い, 各群で最も説明率の高いモデルを採択した（Table 4)。統計的に有意であった予測変数の回帰係数は，全 体で “有益” が $\beta=.390$, “危機支援” が $\beta=.131$, 周 知度が $\beta=.098$, “不気味” が $\beta=-.162,1$ 年生男子 で “有益”が $\beta=.513,1$ 年生女子で “有益”が $\beta=$ .317 , 周知度が $\beta=.207,2-4$ 年生男子で “有益” が $\beta=.509$, 周知度が $\beta=.203,2-4$ 年生女子で “不気 味” が $\beta=-.540$, “危機支援” が $\beta=.305$, “不利益” が $\beta=-.198$ であった。

\section{考 察}

\section{学生相談機関イメージの分類及び周知度と来談意思} の関係 本研究の学生相談機関イメージの 4 因子は, 大きく分けると，どちらかと言えば肯定的なイメージ を表す 2 因子（“有益”，“危機支援”）とどちらかと言 えば否定的なイメージを表す 2 因子（“不利益”，“不 気味”）に分かれるように思われる。また，肯定的イ メージであっても “危機支援”は来談意思への相関及 び回帰係数が “有益”に比べて小さく，否定的イメー ジであっても“不気味”は“不利益”に比へ，相対的 に来談意思への相関及び回帰係数が負の方向に大きか った。すなわち，学生相談機関のイメージには肯定 的・否定的イメージのいずれでも，来談に比較的影響 の大きいイメージとそうでないイメージがあると考え られる。

“有益”と“危機支援”に因子負荷の高い項目から 考えると, 両イメージの差違に学生が抱える問題の深 刻度があると思われる。Kushner \& Sher（1989）は大 学生を対象にした調查から, 苦痛が高まると潜在的な 治療への恐怖が活性化され，回避的な動機づけが高ま ることを指摘しているが，“危機支援”は “有益”に 比へ, 苦痛が高まった状態のイメージであり，このこ とが来談意思を低下させると考えられる。また，“不 利益”と “不気味” の差違は学生相談機関の対応に関 して学生が持っている予備知識の差違によると思われ る。すなわち, “不利益”では学生相談機関の実際の 対応がかなり誤って理解されていることが推測され，

一方の “不気味”では学生相談機関の実際の対応に関 する予備知識がないことが過剩な不安を喚起し，来談 意思を低下させることが推測される。

従来, 本研究のようにイメージを区別してとらえる 研究は見られず, また, 真覚・中村 (1993), 荻原他 (1995), 森田 (1997）の分類と比較しても, 本研究の 因子はより具体的で整理された分類となっていると言 える。本研究の 4 イメージは, 今後, 学生相談機関へ のイメージと来談意思の関連を探る際に有益な視点と なると考えられる。
また，森田（1997）における相談室に来談した“敬 遠群” の学生 2 名は, 本研究では “不気味イメージ” の強い学生に相当すると思われるが, 本研究では来談 していない学生も含めて, 学生相談機関に対する漠然 とした恐怖感を持つ学生は来談に結びつきにくいこと が確認された。

周知度と来談意思の相関は小さかったが，周知度が 高い学生ほど来談意思を高く見積もっている傾向があ ることが示唆された。これは周知度が高くなることに より, 相談する際の心理的な負担が減少して, 来談し やすくなるという仮説を裏付けるものである。

性差・学年差について 性差について検討したとこ ろ, “危機支援”, “不利益”で男子の得点が有意に高 く, 周知度は女子の得点が有意に高かった。アメリカ の研究では, 男子学生は女子学生より専門的援助を利 用することへの志向性が低いことを示す研究が多いが (例えば, Lopez, Melendez, Sauer, Berger, \& Wyssman, 1998）, 今回の調查では，来談意思に性差は見られず， “危機支援”や“不利益”のみに性差が見られた。目 本の男子学生は学生相談機関に対する知識が不足し, “危機支援”ゃ“不利益”の上うに学生相談機関に対 して限定されたイメージや実際とはやや異なるイメー ジを持ちやすいが，そのことは専門的援助への志向性 には大きな影響を及ぼしていないとも考えられる。こ れらの点で日米に差異があることが示唆された。

学年差では, $2-4$ 年生の方が 1 年生より周知度が 高かったが,これは在学期間が長くなるために，学生 相談機関の情報に触れる機会が多くなることによるも のと思われる。一方, 従来, 在学期間によるイメージ の変化については詳しい検討はなかったが, 本研究の 結果から学生相談機関イメージは学年差が見られず, 在学期間の影響を受けにくいと考えられた。これは入 学時のイメージが卒業まで保持される可能性を意味 し，新入生へのオリエンテーションや $2-4$ 年生への 継続的な広報活動の重要性を示唆するものである。

性別・学年別に行った回帰分析の結果から，1 年生 男子・1 年生女子及び 2-4 年生男子では来談意思は “有益イメージ”に依存する面が大きいことが示唆さ 枕。したがって,これらの学生の来談については “有益イメージ”を強化し，問題が重篤になる前に来 談するように働きかけることが効果的であると考えら れる。また， 1 年生女子及び $2-4$ 年生男子では来談 意思は周知度にもある程度依存している。入学時に限 らず，様々な機会に学生相談機関の基本的な情報を伝 えることは, これらの学生の来談に効果を上げること が期待できよう。

これに対し，2-4 年生女子はかなり傾向が異なっ ており, “不気味イメージ”と“不利益イメージ”を 払拭する働きかけと “危機支援イメージ”を高める働 きかけが重要であると考えられる。具体的には，大学 
の学生相談機関における対応をわかりやすく伝えるこ とや，利用者に決して不利益を及ぼさないこと，問題 が重篤になっても利用できる場であること等をアピー ルするような工夫をすることが最も効果的であると考 えられる。

学生相談機関は全学生に対して同じような広報活動 を行うだけではなく，上記のような学年・性別ごとの 特徵をよく把握した上で広報活動を行うことが必要と なろう。

今後の課題 本研究では実験参加者数の関係から調 査を 2 回実施したが, 調査時期の違いにより学生相談 機関の活動に変化がある可能性もあり，十分な人数の 実験参加者を対象とした 1 回の調査で結果を確認する 必要がある。また，学生相談機関の全体的なイメージ を明らかにすることを主たる目的としたため，大学に よる学生相談機関の活動, 利用条件などの差違につい ては検討しなかった。こうした差違が学生の来談に及 ぼす影響についても検討する必要があろう。さらに， イメージの継時的な変化と来談意思との関係, 学生相 談機関へのイメージが形成される過程やイメージを変 容させる方法, 来談した学生と来談しょうと思ったが 実際には来談しなかった学生の差違などについての実 践的な研究も必要となろう。

\section{引用文献}

Blier, M. J., Atkinson, D. R., \& Geer, C. A. (1987). Effect of client gender and counselor gender and sex roles on willingness to see the counselor. Journal of Counseling Psychology, 34, 27-30.

Clary, E. G., \& Fristad, M. A. (1987). Predictors of psychological help seeking on a college campus. Journal of College Student Personnel, 28, 180181.

Fischer, E. H., \& Turner, J. I. (1970). Orientation in seeking help: Development and research utility of an attitude scale. Journal of Consulting and Clinical Psychology, 35, 79-90.

伊藤直樹 (2002). ある大学における学生相談機関の 開設初期の活動——学生相談室再開室加 2 年半 の活動を振り返って——学生相談研究, 23, 185-195.

(Ito, N. (2002) . A case report about activities of a college counseling organization in the early stage in a private college: Review of activities in two years and a half after reopening. Japanese Journal of Student Counseling, 23, 185-195.)

Johnson, D. H., Nelson, S. E., \& Wooden, D. J. (1985). Faculty and student knowledge of university counseling center services. Journal of College Student Personnel, 26, 27-32.

Kahn, J. S., Wood, A., \& Wiesen, F. E. (1999). Student perceptions of college counseling center services: Programming and marketing for a seamless learn- ing environment. Journal of College Student Psychotherapy, 14, 69-80.

Kemp, A. D. (1994) . African-American students' expectations about counseling: A comparative investigation. Journal of Multicultural Counseling and Development, 22, 257-264.

Komiya, N., Good, G. E., \& Sherrod, N. B. (2000). Emotional openness as a predictor of college students' attitudes toward seeking psychological help. Journal of Counseling Psychology, 47, 138-143.

Kushner, M. G., \& Sher, K. J. (1989). Fear of psychological treatment and its relation to mental health service avoidance. Journal of Professional Psychology: Research and Practice, 20, 251-257.

Lopez, F. G., Melendez, M. C., Sauer, E. M., Berger, E., \& Wyssman, J. (1998). Internal working models, self-reported problems, and help-seeking attitudes among college students. Journal of Counseling Psychology, 45, 79-83.

真覚 健・中村雅知 (1993)。学生の相談相手と相談 機関のイメージについての調査 東北大学学生相 談所紀要, 20, 11-22.

(Masame, K., \& Nakamura, M. (1993). Survey on selection of adviser and impressions for counseling institutions. Bulletin of Student Counselors' Office of Tohoku University, 20, 11-22.)

Miles, G. B., \& McDavis, R. J. (1982). Effects of four orientation approaches on disadvantaged black freshmen students' attitudes toward the counseling center. Journal of College Student Personnel, 23 , 413-418.

水野治久・石隈利紀（1999）。被援助志向性，被援助 行動に関する研究の動向 教育心理学研究, 47, 530-539.

(Mizuno, H., \& Ishikuma, T. (1999). Help-seeking preferences and help-seeking behaviors: An overview of studies. Journal of Educational Psychology, 47, 530-539.)

文部省高等教育局・大学に扔ける学生生活の充実に関 する調査研究会 (2000). 大学における学生生活 の充実方策について (報告) 一一学生の立場に立 った大学づくりを目指して——文部省

森 裕子 (1990)。アメリカに扔ける学生相談（コロ ラド州立大学の場合)—その 2 , 活動内容・日 本の学生相談への示唆—— 学生相談研究, 11, 18-31.

(Mori, H. (1990). College counseling in the United States particularly at Colorado State University: Part 2. Services and programs. Student Counseling Journal, 11, 18-31.)

森田美弥子 (1997)。学生相談室イメージと来談の関 係一大学生を対象にして— 心理臨床学研 究, 15, 406-415.

(Morita, M. (1997). The relationship between the image of the counseling center and the counseling process for university students. Journal of Japanese Clinical Psychology, 15, 406-415.)

日本学生相談学会特別委員会 (2001).2000 年度学生 
相談機関に関する調査報告 学生相談研究, 22, 176-211.

(Special Committee of the Japanese Association of Student Counseling (2001). A report on the survey about stundet counseling institutions in 2000. Student Counseling Journal, 22, 176-211.)

西河正行・鈴木典子 (1994). 学生は学生相談室をど のように見ているか? 一一短期大学と専門学校の 学生相談室調査を通して一一慶應義塾大学学生 相談室紀要，22/23，63-76.

(Nishikawa, M., \& Suzuki, N.)

荻原公世・吉川政夫・山田 實 (1995). 学生相談の イメージとあり方——学生相談室に関する調査・ 中間報告—東海大学学生相談室報告, 28, 120-129.

(Ogihara, K., Kikkawa, M., \& Yamada, M.)

櫻井信也・有田モト子（1994）。SD 法による学生相 談センターに関するイメージの測定 学生相談研 究, 15, 10-17.

(Sakurai, S., \& Arita, M. (1994). An image of student counseling center measured by semantic differential method. Student Counseling Journal, 15, 10-17.)

Sanders, J., \& Sanders, R. C. (1985). Faculty members' and students' perceptions of services provided by their counseling center. College Student Journal, 19, 384-388.

下山晴彦・峰松 修 - 保坂 亨 - 松原達哉・林 昭 仁・齋藤憲司 (1991). 学生相談における心理臨 床モデルの研究——学生相談の活動分類を媒介と して—— 心理臨床学研究, 9, 55-69.

(Shimoyama, H., Minematu, O., Hosaka, T., Matsubara, T., Hayashi, S., \& Saitoh, K. (1991). A study on clinical model in the field of student counseling. In terms of classification of the student counseling activities. Journal of Japanese Clinical Psychology, 9, 55-69.)

高野 明・宇留田 麗 (2002). 援助要請行動から見 たサービスとしての学生相談 教育心理学研究, 50, 113-125.

(Takano, A., \& Uruta, U. (2002). Student counseling as a service: From the point of view of helpseeking behavior. Japanese Journal of Educational Psychology, 50, 113-125.)

Tinsley, H. E. A., Workman, K. R., \& Kass, R. A. (1980). Factor analysis of the domain of client expectancies about counseling. Journal of Counseling Psychology, 27, 561-570.

-2003.11.10 受稿, 2005.9.3 受理—— 